\title{
THE FRUCTIFYING RAY: \\ Considering Kandinskian Artistic Creation Through the Hegelian Alienated Consciousness
}

MARTIN FITZGERALD

"The world sounds. It is a cosmos of spiritually affective beings." ${ }^{1}$

\section{INTRODUCTION}

At a particular time necessities come to fruition. i.e., the creating spirit (which one can call the abstract spirit) finds access to the [individual] soul, subsequently to [many] souls, and calls forth a longing, an inner compulsion.

If those conditions are fulfilled which are necessary for a precise form to come to maturity, then this longing, this inner compulsion is empowered to create a new value in the human mind, which, consciously or unconsciously, begins to live within man.

Consciously or unconsciously, from this moment man seeks a material form for this new spiritual value that lives in spiritual form within him.

Thus the spiritual value seeks its materialization. Matter is here a reserve of supplies from which the spirit, like a cook, selects what is n e c e s s a r y in this case.

1 Wassily Kandinsky, "On the Question of Form," in Kandinsky: Complete Writings on Art, Kenneth C. Lindsay and Peter Vergo, eds. (New York: Da Capo Press, 1994), p. 250. 
This is the positive, the creative [element]. This is the good, $\mathrm{T} \mathrm{h} \mathrm{e} \mathrm{w} \mathrm{h} \mathrm{i} \mathrm{t}$ e, fructifyingray.

This white ray leads to evolution, to sublimation. Thus, behind matter, within matter, the creative spirit lies concealed. ${ }^{2}$

$\mathrm{T}$ his short passage both encapsulates many of Kandinsky's major philosophical themes including the internal-external division, the principle of inner necessity, the creating spirit, and artistic evolution and also highlights the difficulty in grounding Kandinsky on a systematic theory of artistic creation. It is difficult to understand the transition from the first inner longing to a concrete contribution to spiritual progress. In particular, it is not clear what this spiritual value is, how it actually becomes materialized, or how the artist selects the necessary matter to materialize it. To address this, I want to call attention to three processes which I will call discernment, wherein the artist realizes what his or her spiritual value is; translation, wherein the artist transforms the spiritual value into a form appropriate to be embodied in an artistic composition; and crafting, wherein the artist physically creates his or her composition. Guiding each of these processes is what Kandinsky calls the 'creating spirit.' I will also look at the work of G.W.F. Hegel in order to help supplement Kandinsky's notion of spirit and to articulate how discernment, translation, and crafting bring a 'spiritually-purposive goal' into being. As we will see, this triadic structure demonstrates the path by which the artist alienates his consciousness from himself in the work of art in order that it may again confront him as an externalized force so as to drive spiritual progress.

In order to make sense of this structure, I will begin by discussing the Hegelian Geist, the way in which Geist alienates from itself, and the way in which alienation contributes to Geist's development. This portion of the Hegelian dialectic will provide a lens through which to interpret Kandinsky's theory. Using this lens, I will discuss Kandinsky's vision of human spiritual progress because every spiritually-purposive goal derives from the artist's position in the collective spiritual atmosphere. Against this backdrop, I will isolate the Kandinskian creating spirit and locate its position alongside what Kandinsky calls the inner need. From here, I will explain the triadic structure of discernment, translation, and crafting in order to demonstrate how the artist produces spiritually-purposive artwork. Finally, I will explain how the process of alienation ends with recuperation whereby the artistic composition returns feedback into the mind of the spectator to produce concrete spiritual progress.

\section{CONSTRUCTING A HEGELIAN LENS}

Hegel's system of philosophy follows the historically-conditioned path of consciousness toward Absolute knowing and Absolute Spirit (the mind that knows and has itself fully as its own subject). For Hegel, consciousness, particularly human

2 Ibid., p. 235. The unusual spacing is transcribed from Kandinsky's own writing. 
consciousness, is the embodiment of reason in the world. The collective embodiment of reason in historically-conditioned consciousness is termed Geist. Hegel believes that Geist by its very nature follows a path through which Truth unfolds. Such a path inevitably takes consciousness out of union with the natural world and into a state of alienation, a fissure that consciousness eventually reunites. Hegel draws upon the Judeo-Christian concept of the Fall to explain this point:

Upon a closer inspection of the story of the Fall we find, as was already said, that it exemplifies the universal bearings of knowledge upon the spiritual life. In its instinctive and natural stage, spiritual life wears the garb of innocence and confiding simplicity; but the very essence of spirit implies the absorption of this immediate condition in something higher. The spiritual is distinguished from the natural, and more especially from the animal, life, in the circumstance that it does not continue a mere stream of tendency, but sunders itself to self-realisation. But this position of severed life has in its turn to be suppressed, and the spirit has by its own act to win its way to concord again. The final concord then is spiritual; that is, the principle of restoration is found in thought, and thought only. The hand that inflicts the wound is also the hand which heals it. ${ }^{3}$

Consciousness not only brings itself out of natural harmony, but also brings itself back into harmony with nature. The reunion with nature is done through a transformation of nature. To "win its way to concord again," spirit:

impregnates the external world with his will. Thereby he humanises his environment, by showing how it is capable of satisfying him and how it cannot preserve any power of independence against him. Only by means of this effectual activity is he no longer merely in general, but also in particular and in detail, actually aware of himself and at home in his environment. ${ }^{4}$

In order to shape the world in its own image, the human consciousness performs work. With work, consciousness shapes an external object in such a way that it can recognize itself in the object:

Man brings himself before himself by practical activity, since he has the impulse, in whatever is given to him, in what is present to him externally, to produce himself and therein equally to recognise himself. This aim he achieves by altering external things whereon he impresses the seal of his inner being and in which he now finds again his own characteristics. Man does this in order, as a free subject, to strip the external world of its inflexible foreignness and to enjoy in the shape of things only an external realisation of himself. ${ }^{5}$

3 G.W.F. Hegel, Hegel's Logic, trans. William Wallace (London: Oxford University Press, 1975), p. 24.

4 G.W.F. Hegel, Aesthetics: Lectures on Fine Art, trans. T.M. Knox (Oxford: Clarendon Press, 1975), p. 256.

5 Ibid. 
This process by which "he impresses the seal of his inner being and in which he now finds again his own characteristics," Hegel calls alienation ${ }^{6}$. In this process of alienation it is not merely the external world which is changed. As Rae notes, alienation provides the consciousness an ability to view itself in a way that it would otherwise not have access to, thereby changing it in the process. ${ }^{7}$ The alienated consciousness is like a mirror which reflects back to the subject what his or her consciousness must really be like in the first place. Pippin points out that "we don't know, in any determinate or 'living' detail, who we actually take ourselves to be except in such externalization, either in action or in such material productions as artworks." In this 'mirror reflection,' consciousness sees not only itself, but also a collective consciousness of Geist in the larger sense.

Individual consciousness, as Hegel claims, is essentially constituted by historical processes, which play out on a societal level. History begins with the break from immediate nature, and, from this point, consciousness itself begins its historical development. This is to say that the very nature of consciousness is constituted by historical, societal forces. As such, even when consciousness is afforded the opportunity to gaze upon itself, it necessarily always sees, knowingly or unknowingly, the society which has formed it into its current state.

Within Hegel's work, alienation is understood in two senses. Alienation is the English word chosen for what are in reality two German words: Entfremdung and Entaüsserung. Rae associates the two words as follows:

Entfremdung describes a process or state where consciousness is separated from, at least, one of the aspects that are required for consciousness to fully understand itself. In contract, 'Entaüsserung' describes the process whereby consciousness externalizes itself in object form and, through this objectification, develops a better understanding of itself. ${ }^{?}$

These two uses of the word are interrelated. Entfremdung, the state of the consciousness before it properly knows its own nature as the universal self, is the state of consciousness after the Fall. Sayers notes, as is consistent with this reading, that this sense of "alienation can and will be overcome when spirit has completed its development and come to be at home in the world." ${ }^{10}$ To progress to where consciousness is at home again in the world, consciousness needs to use Entaüsserung. Entaüsserung is the way in which the conscious subject puts his consciousness before himself in an object in order to be able to observe what his own consciousness is like to gain a better understanding of it. The two senses of alienation are interrelated insofar

6 Ibid.

7 Gavin Rae, "Hegel, Alienation, and the Phenomenological Development of Consciousness," International Journal of Philosophical Studies 20.1 (February 10, 2012), p. 24.

8 Robert B. Pippin, After the Beautiful: Hegel and the Philosophy of Pictorial Modernism, (Chicago: The University of Chicago Press, 2014), p. 41.

9 Ibid.

10 Sean Sayers, "Creative Activity and Alienation in Hegel and Marx," Historical Materialism 11.1 (2003), p. 120. 
as the understanding afforded by Entaüsserung helps reunite the split of consciousness in Entfremdung. Although aspects of Kandinsky's thought resonate with both of these senses of alienation, the focus of this paper is on Entaüsserung, hereafter referred to simply as alienation. Alienation takes place in all categories of work, one of which, artistic work, will be the focus of this paper.

Even though Kandinsky is concerned with artistic work, there is no particular need to invoke pieces of art as distinct from other kinds of objects from a Hegelian perspective for this analysis. In other words, although Hegel has an entire separate theory of aesthetics, we can use Hegelian alienation as a framework for art as a general type of work. If we do as such, then a piece of art is no longer particularly distinct from another object arising from work. Art itself can be understood as a type of work, for work itself finds "its highest expression ... in the free creative activity of art." 11 Artistic creation is still itself an act of work. Although Hegel does clearly draw a distinction between art and other types of objects, the point here is to look at how art is a kind of work and trace alienation within that work. Pippin writes that artistic creation involves alienation as it has been defined above:

Very roughly, Hegel's view was that the production or "externalization" of our ideas in artworks represents a distinct and, until very recently, indispensable form of self- knowledge. His unusual phrase is that the human being, understood as Geist, must "double itself" (sich verdoppeln) (A, 1:31) ... And with that one characterization, we are already in uncharted waters; art does not double or imitate reality as in so many mimetic theories, but rather in art, Geist, some sort of achieved collective like- mindedness, doubles itself. ${ }^{12}$

Thus, it seems fitting to consider the art object in this context. On a basic level, artistic creation is similar to other acts of work insofar as it is the act by which consciousness externalizes itself in order to see and better understand itself as well as to craft the world in its own image. Although it is not necessary to invoke Hegel's aesthetics, it is necessary to give special attention to the art object within Kandinsky's work. Hegel's philosophy provides the opportunity to see the artist as one kind of worker and to see artistic creation as a kind of work alongside other kinds of work. While, again, art is a special kind of work, it still belongs to the general category of work. Kandinsky's writings, however, do not provide this opportunity: in them, artistic creation is necessarily artistic in quality. There is no larger reference to work as a category in Kandinsky's theory. However, Hegel's notion of work can provide this more general category. Alienation provides a Hegelian lens through which to observe how artistic creation works in Kandinsky's theory. In particular, I want to consider the way in which the doubling of consciousness serves as a framework to understand Kandinsky's creative process.

11 Sayers, "Creative Activity and Alienation in Hegel and Marx," p. 113.

12 Pippin, After the Beautiful, p. 32. 


\section{THE ARTIST}

As noted above, the artist is one particular type of determination of consciousness capable of performing work. Although in Hegel's theory any consciousness can perform work which doubles itself, Kandinsky gives an account of the creative process as it relates specifically to an artist. The general mechanisms of Hegelian consciousness, such as self-discovery through alienation, are very much still present within the Kandinskian artist, but with Kandinsky's view the artist does a more specific kind of work. This work is artistic work, what Kandinsky calls the creative act. In the world of spirit, ${ }^{13}$ Kandinsky regards the creative act as essential because art is an irreplaceable instrument in humanity's shared spiritual progress. ${ }^{14}$ The artist, being the one who creates art, is thus a necessary part of spiritual progress himself both through creating individual compositions, as well as using a lifetime's effort to achieve a larger goal. The artist's very existence is meant not to serve his own aims, but rather he exists "exclusively for the sake of the spectator, because the artist is the slave of humanity." ${ }^{15}$ Indeed, the artist:

has a threefold responsibility: (1) he must render up again that talent which has been bestowed upon him; (2) his actions and thoughts and feelings, like those of every human being, constitute the spiritual atmosphere, in such a way that they purify or infect the spiritual air; and (3) these actions and thoughts and feelings are the material for his creations, which likewise play a part in constituting the spiritual atmosphere. He is a 'king', as Sar Peladan calls him, not only in the sense that he has a great power, but also in that he has great responsibilities. ${ }^{16}$

The kind of art which the artist creates in order to effect spiritual progress, Kandinsky calls spiritually-purposive art. Indeed, Kandinsky believes that an artist has a committal responsibility to the non-artist to create spiritually-purposive art. Why is it that the artist occupies such a privileged position for Kandinsky? There are two compelling reasons: one, that the artist is sensitive enough to hear the call of what Kandinsky calls the creating spirit, and two, that the artist is effectively able to alienate his consciousness into an art object through the creative act in such a way that it makes the call of the creating spirit perceptible to a spectator.

The artist's sensitivity to the creating spirit is, in a word, the ability of the artist to determine what spiritual value is necessary to drive spiritual progress. As a gloss, Paul Klee's simile of the tree is a useful comparison. The Kandinskian creating spirit is like the root system of Klee's tree:

13 Not to be confused with the Hegelian Spirit. As written with a lowercase "s," this refers to Kandinsky's understanding of spirit.

14 Wassily Kandinsky, "On the Spiritual in Art," in Kandinsky: Complete Writings on Art, Kenneth C. Lindsay and Peter Vergo, eds. (New York: Da Capo Press, 1994), p. 212.

15 Wassily Kandinsky, "On the Artist," in Kandinsky: Complete Writings on Art, Kenneth C. Lindsay and Peter Vergo, eds. (New York: Da Capo Press, 1994), p. 418.

16 Kandinsky, On the Spiritual in Art, pp. 213-214. 
The artist has studied this world of variety and has, we may suppose, unobtrusively found his way in it. His sense of direction has brought order into the passing stream of image and experience. This sense of direction in nature and life, this branching and spreading array, I shall compare with the root of the tree. From the root the sap flows to the artist, flows through him, flows to his eye. Thus he stands as the trunk of the tree. Battered and stirred by the strength of the flow, he moulds his vision into his work ... Nobody would affirm that the tree grows its crown in the image of its root. Between above and below can be no mirrored reflection. It is obvious that different functions expanding in different elements must produce vital divergences ... standing at his [the artist's] appointed place, the trunk of the tree, he does nothing other than gather and pass on what comes to him from the depths. He neither serves nor rules - he transmits. His position is humble. And the beauty at the crown is not his own. He is merely a channel. ${ }^{17}$

With this line of thought, the artist is said to draw from his or her surrounding life and transmit it into the crown of the tree, which is the artistic composition. In a similar way, the creating spirit is "one's inner impulse ... [that] will inexorably create at the right moment the form it finds necessary," ${ }^{18}$ to give expression to some content. Just as with the roots of Klee's tree, the Kandinskian creating spirit draws from the "passing stream," which is in this case the collective spiritual atmosphere that Kandinsky describes as the "spiritual triangle." ${ }^{19}$ From the spiritual triangle, the creating spirit "calls forth a ... spiritual value [which] seeks its materialization." ${ }^{20}$ Kandinsky does not explicitly state what the content of such a value is or could be, but nevertheless insists that "art in general is not a mere purposeless creating of things that dissipate themselves in a void, but a power that has a purpose and must serve the development and refinement of the human soul - the movement of the triangle." ${ }^{21}$ If spiritually-purposive art is created both to materialize a spiritual value (and no other thing ${ }^{22}$ ), as well as to raise the spiritual triangle, then the spiritual value is one which, when materialized, directs itself towards raising the spiritual triangle.

The process of materialization - the creative act - takes place through a Hegelian alienation of the artist's consciousness into the artistic composition. In this process, the artist, through contact with the creating spirit, must first determine what spiritual value is necessary and suitable to express. Then, the artist must comprehend the way in which this value is capable of being materialized in an artistic composition. Finally, the artist must then proceed to make this composition. When performed correctly,

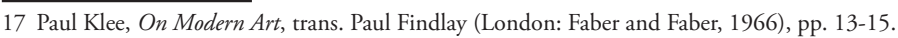

18 Wassily Kandinsky, "Cologne Lecture," in Kandinsky: Complete Writings on Art, Kenneth C. Lindsay and Peter

Vergo, eds. (New York: Da Capo Press, 1994), p. 396.

19 See section The Spiritual Triangle

20 Kandinsky, "On the Question of Form," p. 235.

21 Kandinsky, On the Spiritual in Art, p. 212.

22 Kandinsky acknowledges that many different forces affect the production of a piece of art but nevertheless states that only the inner spiritual value is the true goal of the piece of art. Epoch, personality, and so forth give rise to artistic expression, but are not the goal of a piece of art. 
the artist produces a spiritually-purposive composition which embodies his or her externalized consciousness.

\section{THE SPIRITUAL TRIANGLE}

Spiritually-purposive art is only spiritually-purposive if it contributes to the advancement of the collective spiritual atmosphere. Kandinsky elaborates this viewpoint in the first four chapters of On the Spiritual in Art with the simile of the "spiritual triangle." 23 All of humanity's collective spiritual life:

can be accurately represented by a diagram of a large acute triangle divided into unequal parts, with the most acute and smallest division at the top. The farther down one goes, the larger, broader, more extensive and deeper become the divisions of the triangle. The whole triangle moves slowly, barely perceptibly, forward and upward so that where the highest point is 'today'; the next division is 'tomorrow,' i.e. what is today comprehensible only to the topmost segment of the triangle and to the rest of the triangle is gibberish, becomes tomorrow the sensible and emotional content of the life of the second segment. ${ }^{24}$

Due to the geometry of the triangle, there are fewer and fewer people in each level as the apex is approached; the majority of people fall within one of the lower levels. At the very top level "stands sometimes only a single man" ${ }^{25}$ who, through his efforts alone, brings the triangle towards tomorrow. This person is analogous to Hegel's notion of the world-historical individual. World-historical individuals are "agents of the World-Spirit," meaning that they have "an insight into the requirements of the time." 26

This was the very Truth for their age, for their world; the species next in order, so to speak, and which was already formed in the womb of time. It was theirs to know this nascent principle; the necessary, directly sequent step in progress, which their world was to take; to make this their aim, and to expend their energy in promoting it. World-historical men - the Heroes of an epoch - must, therefore, be recognized as its clear-sighted ones; their deeds, their words are the best of that time. ${ }^{27}$

Kandinsky locates the apex of the triangle similarly. The visionary at the apex hears the voice of spirit and opens the way to "the spiritual bread for the spiritual awakening now beginning." ${ }^{28}$ His progress is a progress for all in that the work of the visionary advances the triangle absolutely. Even if the fruits of his innovations are

23 Kandinsky, On the Spiritual in Art, p. 133.

24 Ibid.

25 Ibid.

26 Hegel, G.W.F., The Philosophy of History. Ontario: Batoche Books, 1900. https://www.marxists.org/reference/ archive/hegel/works/hi/introduction-lectures.htm\#s1.

27 Ibid.

28 Kandinsky, On the Spiritual in Art, p. 138. 
not immediately felt by all, the progress still stands as a universal progress. However, not everyone has direct access to this progress. Instead, it is the unique role of the artist to make spiritual values available to non-artists. Just like non-artists, Kandinsky notes that artists have different degrees of spiritual development and as such reside in different segments of the triangle. Thus:

In every division of the triangle, one can find artists. Every one of them who is able to see beyond the frontiers of his own segment is the prophet of his environment, and helps the forward movement of the obstinate cartload of humanity. ... It is obvious that every such segment hungers - consciously or (much more often) completely unconsciously - after its corresponding spiritual bread. This bread is given it by its artists, and tomorrow the next segment will reach for that same bread. ${ }^{29}$

And, in this way, the progress of the apex is ostensibly the progress of all. Once the apex has broken into new ground, the new ground is separated from others only by a train of "tomorrows."

Kandinsky believes that all pure art is spiritually-purposive art, which is to say that all pure art furthers the advance of the spiritual triangle. According to Kandinsky, art is uniquely and exclusively positioned to perform this function. Thus, "art is for this reason indispensable and purposeful," ${ }^{30}$ because "there is no other power that can replace art." ${ }^{\prime 1}$

Just, then, as work is crucial to the development of Geist, so too is the creative act crucial to the development of Kandinskian spirit. If spiritual progress requires the production of art, then a form of work, the work which produces art, is necessary to raise the spiritual triangle. This work must take the creating spirit and inner need as its guidance, proceeding from contact with the spiritual triangle.

\section{COMPOSITION}

An artistic composition is the material result of the creative act. In it resides the artist's externalized consciousness in the form of a concrete pictorial goal. A composition is distinct from the more general term 'art object.' Kandinsky offers several different definitions for the word, each of which slightly different from, but not excluding, the others. First, a composition is "the internally purposive subordination of individual elements [and] of the structure to a concrete pictorial goal." ${ }^{32}$ The elements themselves are defined as "the concrete result produced by force operating upon the material," where "tensions, for their part, give expression to the inner sound of the element." 33

29 Ibid., p. 134.

30 Wassily Kandinsky, "On Stage Composition," in Kandinsky: Complete Writings on Art, Kenneth C. Lindsay and

Peter Vergo, eds. (New York: Da Capo Press, 1994), p. 258.

31 Kandinsky, On the Spiritual in Art, p. 212.

32 Wassily Kandinsky, Point and Line to Plane, in Kandinsky: Complete Writings on Art, Kenneth C. Lindsay and Peter Vergo, eds. (New York: Da Capo Press, 1994), p. 552.

33 Ibid, p. 611. 
Thus it is also appropriate to call a composition "the logically precise organization of ... living forces encapsulated within elements in the guise of tensions." ${ }^{44}$ An element's inner sound is a "spiritual being possessing qualities which are identical to that form." 35

These inner sounds are what communicate with the spectator spiritually. In addition to internal effect produced by inner sound, every color, form, and object in a composition also has an external effect. Kandinsky's writing is concerned with measuring internal effect through external forms, and not with measuring external effect itself. Inner sounds awaken movements in the spirit through the sense which experiences the art. For example, Kandinsky describes "color [as] a means of exerting a direct influence upon the soul. Color is the keyboard. The eye is the hammer. The soul is the piano, with its many strings." ${ }^{36}$ Similarly, "form itself, even if completely abstract, resembling geometrical form, has its own inner sound." 37 Outside of painting, "musical sound has direct access to the soul. It finds there an echo, for man 'hath music in himself'." 38 In other words, inner effect is a property of artistic compositions in general, not merely of paintings. It is necessary to note, however, that each discipline of art has its own peculiarities. Although one can represent the same inner effect in both painting and music, the two effects can never be the same; "each art has its own forces, which cannot be replaced by those of another art." 39

Because an artistic composition is a physical thing, the inner sound is necessarily revealed through some sort of contact with the material of the composition. However, curiously, Kandinsky notes that there are kinds of music which "lead us into a new realm, where musical experiences are no longer acoustic, but purely spiritual." 40 Kandinsky seems to be saying that, despite the material nature of a composition (in the case of music, acoustic vibrations produced from physical instruments), the spiritual effect can offer itself up directly, as though the material did not exist at all. "The manner of listening to a 'pure' musical work is identical to that of seeing a work of 'concrete' painting." 41

A work of art is pure when all of its elements are chosen and arranged by necessity. In analyzing Kandinsky's tableau Thirty, Florman finds a striking similarity between the arrangement of forms in the painting and the composition and function of Hegel's ideal state. She cites Frederick Beiser's analysis:

First, the whole exists for each of the parts as much as each of the parts exists for the whole; in other words, the individual is as much a means as

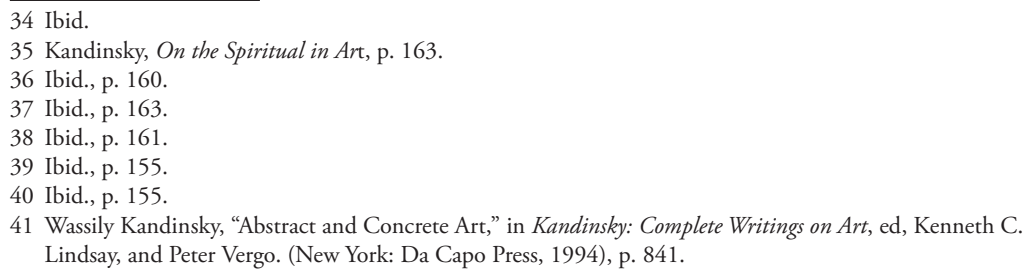


an end for the state. Second ... there must be life in each part of the state, so that each has some degree of autonomy and independence. Third, each part, in maintaining itself and seeking its own self-interest, also promotes the interest of the whole. ${ }^{42}$

Florman uses this analysis of the state to make sense of Thirty's highly variegated structure, noting that "it's these independent units, mediating between the Kraft or power of the whole and the variety of the particular, often opposed forces pulling the smaller parts in one direction or the other, that give the comparison whatever plausibility it has." ${ }^{33}$ The comparison, however, stretches further. Kandinsky understands compositions as a general form as "the internally purposive subordination $\ldots$ of the individual elements and ... of the structure (construction) to a concrete pictorial goal." ${ }^{44}$ Thus, while Thirty might be the painting through which Kandinsky most explicitly states this relationship, Kandinsky's elements-based approach means that the "organic model" 45 of Hegel's state applies equally well to all of his proper compositions. This also helps make sense of Florman's other observation: that "in his ideal state, Hegel had assigned a crucial role to independent bodies - civic corporations of one kind or another - which were charged with reconciling the conflicting claims of community and freedom." 46 Kandinsky believes that within a composition, "independent ... complexes can be subordinated to other, still larger, ones which themselves form only part of the overall composition." ${ }^{77}$ While the end result of the creative act is a unified composition, the composition nevertheless contains smaller organs within it, which are compositions in their own right.

For the comparison to hold, then the elements' existence must be as dependent on the composition as the composition is on the elements, just as the individual is just as much a means as an end for the state. If an element is to be understood as simply a physical form on the canvas then the comparison falls apart, for the physical form exists outside of its organization into a composition. Crucially, however, Kandinsky has defined an element as an "encapsulated tension." The tension is dependent on the hand of the artist, who alienates his consciousness to create that particular element. Kojève reaches a similar conclusion in his essay "The Concrete Paintings of Kandinsky," raising the example of a drawing "in which Kandinsky incarnates a Beautiful [sic] involving a combination of a triangle with a circle:" 48

Just as the tableau "represents" nothing external to it, its Beautiful is also purely immanent, it is the Beautiful of the tableau that exists only in the tableau. This Beautiful was created by the artist, just as was the circle-

\footnotetext{
42 Florman, Concerning the Spiritual and the Concrete in Kandinsky's Art (Stanford, CA: Stanford University Press, 2014), p. 64 .

43 Ibid.

44 Kandinsky, Point and Line to Plane, p. 552.

45 Florman, Concerning the Spiritual and the Concrete in Kandinsky's Art, p. 64.

46 Ibid.

47 Kandinsky, Point and Line to Plane, p. 616.

48 Florman, Concerning the Spiritual and the Concrete in Kandinsky's Art, p. 163.
} 
triangle that embodies it. The circle-triangle does not exist in the real, nonartistic world; it does not exist before, outside of, or apart from the tableau; it was created in and by - or as - the tableau. ${ }^{49}$

Florman's comparison to Hegel's ideal state is apt in more ways than she states. The artist's concrete goal both determines and is determined by the artistic elements which embody it. Yet, there is still a gap between the between the work of the creating spirit and the finished composition. The artist has to pass through a triadic stage of creation whereby the artist realizes his or her spiritual value (discernment), morphs it into a form appropriate to an artistic composition (translation), and then create the actual material composition (crafting) ${ }^{50}$

\section{DISCERNMENT}

To begin the process of alienation, the artist must determine what spiritual value is necessary to drive spiritual progress. Although the artist has contact with the creating spirit for this purpose, the spiritual value to be materialized does not arrive in a finished form, nor in a way which can be directly cognized. Kandinsky suggests that the creative spirit implants the value only as a latent potentiality; it arrives as a longing. It is only later that "if those conditions are fulfilled which are necessary for a precise form to come to maturity, then this longing, this inner compulsion, is empowered to create a new value in the human mind." ${ }^{1}$ In other words, the artist does not originally possess the value in its final form. The artist only comes to possess the value through realizing a "precise form," which empowers the longing. ${ }^{52}$ As such, to realize what value the artist must embody in his artwork is dependent on contact with the physical world. I call the process by which the artist comes to realize his value discernment.

Kandinsky himself suggests two conditions through which the precise form can be recognized: the external condition and the internal condition. The internal condition is the power of the human spirit to hear the call of the creating spirit which "impels the human spirit forward and upward." 53 The external condition is the condition whereby "no barriers stand in the way," of "evolution, progress forward and upward." 54 Kandinsky mentions these conditions are necessary to bring a longing to fruition. Thus, the implantation of the longing takes place prior to these two conditions.

Discernment is thus guided by the creative spirit, which is the artist's own inner impulse, through the two conditions, internal and external, in order to find the

49 Ibid.

50 None of these terms exist in Kandinsky's actual texts, nor does he allude to such a triadic process. However,

I believe the triadic movement to be the correct reading of his account of the creative act, not a Hegelian imposition.

51 Kandinsky, “On the Question of Form,” p. 235.

52 I understand 'form' to refer to the material art object which can embody the value. This use of 'form' is consistent with both the term as it is generally used in Kandinsky's work as well as within this particular essay.

53 Ibid., p. 236.

54 Ibid. 
precise form which converts the inner longing into a new value which lives "in a spiritual form within him." 55 What is the event, or events, which causes, or cause, the conversion of a longing into a value? One thing is certain, that the artist must to some degree look outside him or herself to do this. The inner longing is temporally conditioned (hence why it only arises at a particular time), which is to say that the longing is a historical event. The conversion of a longing into a value is done through the discovery of a form. This, too, is historically conditioned, for "form is always temporal, i.e. relative, since it is nothing more than the means necessary today, the means which the revelation of today sounds forth, manifests itself." ${ }^{\prime 6}$ Form itself is subject to both "time (period) and space (nationality)." ${ }^{57}$ Because form is temporally conditioned, the artist does not freely imagine a precise form. The artist can only discover this necessarily temporal form through contact with the temporal world. Even the value itself is one which participates in the "continual triumph of new values," 58 which, insofar as they drive the evolution of humanity as a whole, rely on a temporal spectator. In the same way that the Hegelian world-historical individual is not simply just a great person, but one who is intensely aware of Spirit as it is in the world at the moment, so too is the great artist one who is intensely aware of the spiritual needs of the age.

The question still remains, however, the extent to which the artist's contact with the outside world can be done spiritually, materially, or otherwise. Does the artist discover his or her precise form through pure thought, through observing other forms, or through some other means? Whatever the case, once the artist has discerned his or her spiritual value, the artist must produce a piece of art to embody that value. To do so, the artist translated that value into a concrete pictorial goal.

\section{TRANSLATION}

The artist advances the spiritual triangle by disseminating his new value through his artwork. To do so, the artist must translate the spiritual value into a mode which can actually guide the creation of an art object. "From [the] moment," when the artist realizes the precise form of his value, he "seeks a material form for this new value that lives in a spiritual form within him." ${ }^{59}$ Translation is the process whereby the artist comes to discover which artistic spiritual effect is capable of materially embodying the spiritual value found through discernment. An artwork embodies the value through possessing a combined spiritual effect which resonates with the spectator in such a way as to inspire that value in the spectator as well. Thus, Kandinsky says that "every phenomenon in both external and internal worlds can be given linear expression - a kind of translation" ${ }^{00}$ and also notes the existence of such translations in other art

55 Ibid., p. 235.

56 Ibid., p. 237. Kandinsky's emphasis.

57 Ibid. Kandinsky's emphasis.

58 Ibid., p. 236.

59 Ibid., p. 235.

60 Kandinsky, Point and Line to Plane, pp. 583-584. 
forms such as music as well. The result of the translation, the spiritual effect, we may rightly call the goal of the composition as the artist relates to it. The artist's aim is to create a composition with the guidance of the translated spiritual value. This agrees with Kandinsky's essay "On Stage Composition" where he identifies "the goal of a work of art" as "a certain complex of vibrations." ${ }^{11}$

The spiritual effect of the composition is not the same thing as the value which it embodies, nor can one proceed directly from a spiritual value to a spiritual effect, which is why translation is a necessary step in the creative process. This is due to the inherent metaphysical properties of artistic compositions in Kandinsky's thought and not merely due to the way the creating spirit acts in the artist. First, the nature of art makes it impossible to translate the goal purely rationally. Kandinsky bites the bullet and "abandon[s] the realm of objective reasoning" by stating that "the artist can never either grasp or recognize fully his own goal." 62 This points to the fact that each category of art adds its own peculiarities to the same internal effect and that the internal effect of an element is dependent on the context it is put in. The key to translation is that the artist does not proceed directly from the imagined spiritual value to a fully translated pictorial goal. Rather, the artist has to understand the value from the side of the composition. Translation imagines what spiritual effect within a composition will inspire the spiritual value in the spectator through internal effect. Where each category of art has its own peculiarities in internal effect, the artist can only understand the combined effect through understanding how each kind of art modifies the entire spiritual effect of the composition. Thus, a proper examination of the properties of artistic forms is the only way to determine how the artist can perform a translation.

In his "Cologne Lecture," Kandinsky notes his discovery of what Florman calls "color's fundamental mutability." ${ }^{63}$ The actual inner sound of a color can be "redefined ad infinitum by its different uses," ${ }^{64}$ as opposed to being constant across all paintings. What appears to be a warm color can be made cool in a particular use. This means that the artist cannot reliably use the same color or form to achieve the same spiritual effect repeatedly, as the spiritual effect will change, even drastically so, depending on the other elements of the composition. For translation, this means that the artist has to imagine and/or create a substantial portion of the composition before being able to imagine how each individual form is affected by the others. The inner sound is constantly changing as more elements are added, which is problematic because there is an infinite number of inner sounds, so an element can frequently come to possess an inner sound previously unknown.

61 Kandinsky, “On Stage Composition," p. 257.

62 Kandinsky, "Cologne Lecture," p. 399.

63 Florman, Concerning the Spiritual and the Concrete in Kandinsky's Art, p. 85.

64 Kandinsky, “Cologne Lecture," p. 398. 
Further, "each art has its own forces, which cannot be replaced by those of another art." ${ }^{65}$

Where do the differences lie? Kandinsky notes that "in the last essentials, these means," the material forms, "are wholly alike: their final goal extinguishes their external dissimilarities and reveals their inner identity." ${ }^{\text {" Th }}$ This is not to say that the inner effect of two kinds of art can be identical, for "an exact 'translation' of one art to another is impossible." ${ }^{\prime 67}$ Rather the implication is that their identity as spiritually affective art is preserved across category. If the dissimilarity is not due to identity, for they are both spiritually affective art forms at base, and is not due to limitations in inner sound, then the dissimilarity is to be found in the difference in material between categories of art. The affectivity of a certain kind of art owes to the material proper to that kind of art. This means that matter itself has a kind of affectivity peculiar to it. In the process of translation, the artist imagines the concrete pictorial goal in terms of the material they intend to use. But, because the matter is affective in a special way, one which the artist can never fully grasp, the artist cannot immediately determine how the goal is to be translated. Thus, "nothing is more damaging and more sinful than to seek one's forms by force." 68

The artist cannot directly impose himself on the matter because he cannot grasp the translated goal without mediation, hence the sinfulness of forcing forms. However, the artist is capable of perceiving the translated goal in the finished composition even if he is not capable of dictating exactly what it is he perceived. This means the artist can place himself in the presence of the translated goal by the mediation of spiritually affective matter. This is not to say that the artist necessarily approaches the canvas in a state of paralysis, but rather is to say that translation is never complete as a purely mental phenomenon alone.

Indeed, the impossibility of translation as a purely mental phenomenon points towards the very root of the process of alienation. The goal of a composition, as we have seen, springs forth from the creating spirit, which itself springs forth from the artists' consciousness. In other words, the goal of the composition is created by, and is held in, the artist's consciousness. However, as Hegel says, the consciousness cannot simply observe itself as it truly is. Instead, consciousness must observe itself through alienation by recognizing itself in an external object. In this case, the creative act is the work which invests consciousness in an external object, the composition, and allows the artist to recognize himself. Hence, the artist cannot simply immediately realize his translated goal, as to do so would be to observe consciousness directly. Rather, the artist must first begin crafting his composition.

65 Kandinsky, On the Spiritual in Art, p. 155.

66 Kandinsky, "On Stage Composition," p. 257.

67 Kandinsky, "Abstract and Concrete Art," p. 841.

68 Kandinsky, “Cologne Lecture,” p. 396. 


\section{CRAFTING}

Creation is the actual physical process by which the artist creates the art object which will materialize the spiritual value by embodying the value's translation into artistic spiritual effect. In crafting, the goal serves to guide which forms must be placed by inner necessity. Crafting includes things such as painting, sculpting, writing, or any such physical activity. As with translation and discernment, crafting is a necessary step in the creative process, especially insofar as the result of crafting, the composition, is what mediates the spiritual value back into the spiritual triangle. An artist creates a composition by combining the elements proper to the type of art they are working in as guided by the goal they wish to create. For example, graphic art features the point and the line.

Kandinsky does not speak much about the actual physical process of crafting. Indeed, to speak too much of it would risk a descension into "virtuoso painting," ${ }^{69}$ or painting that focuses on external effect rather than internal effect. However, he does mention that form must "enter into the work of art of its own accord, and, moreover, at that level of completeness which corresponds to the development of the creative spirit." The physical "matter is here a reserve of supplies from which the spirit, like a cook, selects what is necessary in this case."11 There are many different ways to produce forms just as there are many different categories of art. Point and Line to Plane makes a particular study of etching, woodcutting, and lithography to demonstrate how different technical methods can impact the inner sound of certain elements. Each of these three crafting techniques gives a point "various faces and hence various expressions."72 As a grouping, "technical resources arise no less intentionally and purposively than all other phenomena, both in the "material" world (spruce, lion, star, louse) and in the "spiritual" (work of art, moral principle, scientific method, religious idea)."73

As the artist gazes at the forms he has created, he becomes a spectator to his own work. The artist's own composition as it is being crafted inspires a spiritual effect in the artist himself. This can help the artist further realize his own spiritual value or realize exactly how it is that value translates into a concrete pictorial goal.

\section{COLLAPSE OF THE TRIAD}

The separation of the creative act into each of these three stages contains within it a problem. Each of the three stages requires something outside of itself to reach completeness, indeed even to begin in the first place. Discernment requires recognition of a precise form for the spiritual value to make itself apparent. If the

69 Kandinsky, "On the Artist," p. 412.

70 Kandinsky, “Cologne Lecture," p. 396.

71 Kandinsky, "On the Question of Form,” p. 235.

72 Kandinsky, Point and Line to Plane, p. 566.

73 Ibid., p. 563. 
precise form is to be appropriate for the spiritual value, then the value must already be conceived of as a translated value. However, translation requires contact with the material of the composition because the inner sound of the elements is unknowable in isolation. Because the artist cannot fully imagine the inner sound of each element without viewing the element's inner sound in juxtaposition with other sounds, the artist cannot perfectly picture a complete canvas in his head before the piece has been created. Translation is thus only approximate at best until the artist sees how the inner sounds of familiar elements are modified by their juxtapositions. Likewise, crafting requires a concrete pictorial goal to choose and order the elements. The artist must choose elements in accordance with the translated goal, which is itself dependent on the artist's discernment of the spiritual value, which is itself dependent on realizing the precise form of the composition. The artistic process seems to be at a standstill. Each stage requires something from the other stage in order to proceed.

Hegel himself recognizes a similar problem in the Phenomenology of Spirit in chapter 5, C "Individuality which Takes Itself to be Real in and for Itself":

Consciousness must act merely in order that what it is in itself may become explicit for it; in other words, action is simply the coming-to-be of Spirit as consciousness. What the latter is in itself, it knows therefore from what it actually is. Accordingly, an individual cannot know what he [really] is until he has made himself a reality through action. However, this seems to imply that he cannot determine the End of his action until he has carried it out; but at the same time, since he is a conscious individual, he must have the action in front of him beforehand as entirely his own, i.e. as an End. The individual who is going to act seems, therefore, to find himself in a circle in which each moment already presupposes the other, and thus he seems unable to find a beginning, because he only gets to know his original nature, which must be his End, from the deed, while, in order to act, he must have that End beforehand. But for that very reason he has to start immediately, and, whatever the circumstances, without further scruples about beginning, means, or End, proceed to action; for his essence and intrinsic nature is beginning, means, and End, all in one. ${ }^{74}$

The "End" here is analogous to the artist's concrete pictorial goal and the deadlock is much the same. How can the artist proceed, oriented towards the concrete pictorial goal, that is, his End, when that End is only found through the action? If the End must be had beforehand, it seems impossible to proceed. However, where the End springs forth from consciousness itself, the deadlock can be broken. Because the artist alienates his own consciousness as the concrete pictorial goal, the intrinsic nature of that very consciousness contains the beginning, means, and End within it already. It is immediate action which leads to the end of the creative act.

74 Hegel, G.W.F., Phenomenology of Spirit, trans. A. V. Miller, (Oxford University Press, 1977), p. 240. 
Florman, while having a different account for the creative act, nonetheless arrives at a similar conclusion. Through her analysis, Florman has also identified a triadic creative process. In the first moment the artist lays in the main body of the composition, in the second moment he balances the individual elements against one another, and in the third the artist makes tiny alterations in color to profoundly alter the combined effect. ${ }^{75}$ Florman notes that "the implication here is that the painting's completion turned on a process not wholly, not even primarily, within the artist's conscious control. Especially at this third stage, Kandinsky would have us know, progress was driven by painting's own logic or 'inner necessity."'76 Florman's description picks up after implantation of the inner longing, ${ }^{77}$ but nevertheless demonstrates something profound about Kandinsky's account of the creative process in agreement with Hegel: that true distinctions between moments of the creative process are ultimately untenable. Even if the artist lays out the main forms first, the forms are not the same in essence as the final forms. As was said above, ${ }^{78}$ the elements and goal are mutually constitutive. If the goal changes after the main forms are laid in, then those forms change as well. It is in this same way that discernment, translation, and crafting collapse into one another.

\section{CONCLUSION}

At the end of the creative act, the artist's externalized consciousness lies ready to re-confront itself in the completed composition. The triadic movement described above ultimately sunders into the more general process of alienation. Now latent in the composition is consciousness as implanted through a concrete pictorial goal in the creative act. In order to drive spiritual progress, the composition now offers itself up to the spectator; for, after all, the artist exists "exclusively for the sake of the spectator, because the artist is the slave of humanity." 79 The spiritual bread offered in the composition is a spiritual value created by the artist's own inner impulse under the guise of the creating spirit. Truly, then, the artist offers his own consciousness up as the people's spiritual bread. In doing so, "in rendering itself objective and making this [-] its being [-] an object of thought, [spirit,] on the one hand, destroys the determinate form of its being, and, on the other hand, gains a comprehension of the universal element which it involves and, thereby, gives a new form to its inherent principle ... [which] has risen into another, and, in fact, a higher principle." The higher principle is still shrouded in mystery for Kandinsky, but he nevertheless maintains conviction that the spiritual triangle moves ever upward. It is only through Hegel's theory of alienation, however, that the movement of the triangle is given its fullest expression, for in it we see that the creative act is itself the movement of consciousness from the triangle into the composition through the artist's hand.

75 Florman, Concerning the Spiritual and the Concrete in Kandinsky's Art, p. 85.

76 Ibid.

77 See Discernment

78 See Composition

79 Kandinsky, "On the Artist," p. 418. 


\section{BIBLIOGRAPHY}

Florman, Lisa Carol. Concerning the Spiritual and the Concrete in Kandinsky's Art. Stanford, CA: Stanford University Press, 2014.

Hegel, G.W.F. Aesthetics: Lectures on Fine Art. Translated by T. M. Knox, Oxford: Clarendon Press, 1975.

Lectures on the Philosophy of History. Translated by John Sibree. New York: Henry G. Bohn, 1861.

Phenomenology of Spirit. Translated by. A. V. Miller. Oxford University Press, 1977.

The Philosophy of History. Ontario: Batoche Books, 1900. https://www. marxists.org/reference/archive/hegel/works/hi/introduction-lectures.htm\#s1.

Kandinsky, Wassily. "Abstract and Concrete Art." Kandinsky: Complete Writings on Art, Kenneth C. Lindsay and Peter Vergo, eds. p. 840. New York: Da Capo Press, 1994.

“Cologne Lecture." Kandinsky: Complete Writings on Art, Kenneth C. Lindsay and Peter Vergo, eds. pp. 392-400. New York: Da Capo Press, 1994.

"On the Spiritual in Art." Kandinsky: Complete Writings on Art, Kenneth C. Lindsay, and Peter Vergo, eds. pp. 114-219. New York: Da Capo Press, 1994.

"On Stage Composition” Kandinsky: Complete Writings on Art, Kenneth C. Lindsay and Peter Vergo, eds. pp. 257-264. New York: Da Capo Press, 1994.

"On the Artist." Kandinsky: Complete Writings on Art, Kenneth C. Lindsay, and Peter Vergo, eds. pp. 407-418. New York: Da Capo Press, 1994.

"Point and Line to Plane." Kandinsky: Complete Writings on Art, Kenneth C. Lindsay, and Peter Vergo, eds. pp. 524-699. New York: Da Capo Press, 1994.

Klee, Paul. On Modern Art. Translated by Paul Findlay. London: Faber and Faber, 1966.

Hegel, G.W.F. Hegel's Logic. Translated by William Wallace. London: Oxford University Press, 1975.

Pippin, Robert B. After the Beautiful: Hegel and the Philosophy of Pictorial Modernism. Chicago: The University of Chicago Press, 2014.

Rae, Gavin. "Hegel, Alienation, and the Phenomenological Development of Consciousness." International Journal of Philosophical Studies 2012. 20.1 pp. 23-42

Sayers, Sean. "Creative Activity and Alienation in Hegel and Marx." Historical Materialism 2003. 11.1 pp. 107-28. 